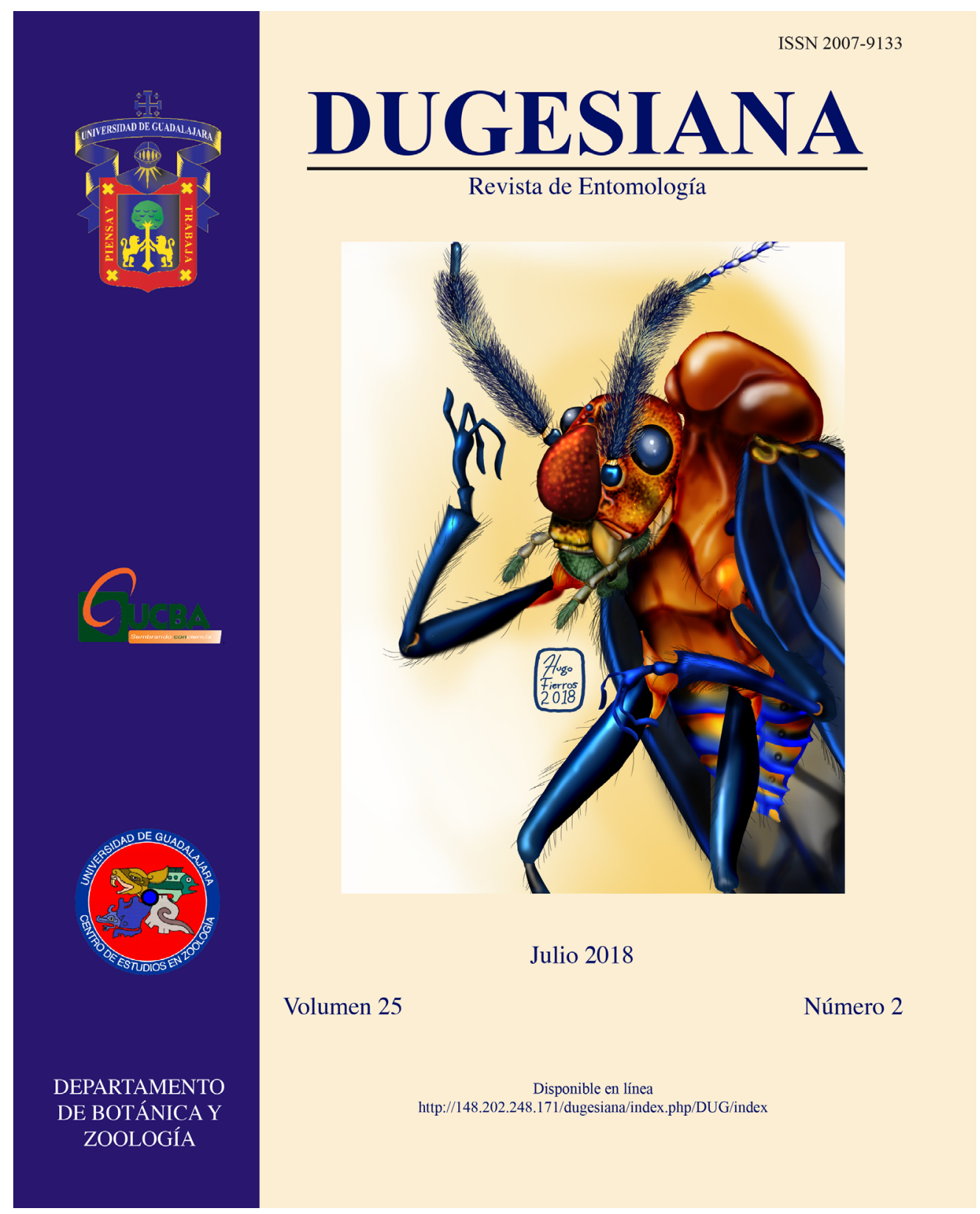

Dugesiana, Año 25, No. 2, julio 2018-diciembre 2018 (segundo semestre de 2018), es una publicación semestral, editada por la Universidad de Guadalajara, a través del Centro de Estudios en Zoología, por el Centro Universitario de Ciencias Biológicas y Agropecuarias. Camino Ramón Padilla Sánchez \# 2100, Nextipac, Zapopan, Jalisco, Tel. 37771150 ext. 33218, http://148.202.248.171/dugesiana/index.php/DUG/index, glenusmx@gmail.com. Editor responsable: José Luis Navarrete Heredia. Reserva de Derechos al Uso Exclusivo 04-2009-062310115100203, ISSN: 2007-9133, otorgados por el Instituto Nacional del Derecho de Autor. Responsable de la última actualización de este número: José Luis Navarrete Heredia, Editor y Ana Laura González-Hernández, Asistente Editorial. Fecha de la última modificación 25 de julio 2018, con un tiraje de un ejemplar.

Las opiniones expresadas por los autores no necesariamente reflejan la postura del editor de la publicación.

Queda estrictamente prohibida la reproducción total o parcial de los contenidos e imágenes de la publicación sin previa autorización de la Universidad de Guadalajara. 


\title{
A new species of Lachesilla (Psocodea: Psocomorpha: Lachesillidae), in species group Corona, from Chiapas, Mexico
}

\author{
Una nueva especie de Lachesilla (Psocodea: Psocomorpha: Lachesillidae), en el grupo de especies \\ Corona, de Chiapas, México
}

\author{
Alfonso N. García Aldrete ${ }^{1} \&$ Alberto Moreira da Silva Neto ${ }^{2}$ \\ 'Departamento de Zoología, Instituto de Biología, Universidad Nacional Autónoma de México, CdMx, MÉXICO. \\ E-mail: anga@ib.unam.mx; ${ }^{2}$ Instituto Nacional de Pesquisas da Amâzonia-INPA. CPEN- Programa de Pós- \\ Graduaçao em Entomologia. Campus II. Caixa Postal 478, CEP 69011-97, Manaus, Amazonas, BRASIL. E-mail: \\ bio.alberto@gmail.com
}

\begin{abstract}
A new species of Lachesilla, from the Mexican state of Chiapas, is described and illustrated, it is assigned to species group Corona on basis of the paraprocts, epiproct, and phallosome apodemes; the hypandrium and claspers do not seem to fit well into species group Corona.

Key words: Taxonomy, neotropics, 'Psocoptera', southeastern Mexico.

\section{RESUMEN}

Se describe e ilustra una nueva especie de Lachesilla, del estado de Chiapas, México, asignada al grupo de especies Corona, con base en los paraproctos, epiprocto, y apodemas del falosoma, aunque el hipandrio y los clásperes no parecen encajar bien en el grupo de especies Corona.

Palabras clave: Taxonomía, neotrópico, 'Psocoptera', sureste de México.
\end{abstract}

With 341 species described, and at least 100 species undescribed, but already available in collections, the spectrum of morphological variation in the psocid genus Lachesilla is flabbergasting.

In an attempt to organize that enormous diversity, the 341 described species have been assigned, based on their phenetic similarity, to 19 species groups. In addition, 10 undescribed species are included in species group $Q$ (García Aldrete, 1974, 1981, 1982, 1983, 1985, 1986, 1990 , 2009, 2010, 2011a, 2014; Mockford, 1993; García Aldrete \& Mockford, 2011).

Chiapas is one of the five Mexican states most species rich for psocids (Mockford \& García Aldrete, 1996). In 2011b, García Aldrete recorded 210 species, which is equivalent to $28.1 \%$ of the total for Mexico, and of these 57 corresponded to the genus Lachesilla. One of those species, represented by a single male, is here described and illustrated, it is assigned in species group Corona, although the hypandrium and claspers do not fit well into that group.

\section{MATERIAL AND METHODS}

One male specimen was available for study. It was dissected in $80 \%$ ethanol, and its parts (head, right antenna, right wings and legs, and genitalia), were mounted on a slide in Canada balsam, following standard procedures. The parts on the slide were measured with a filar micrometer; abbreviations of parts measured are the following: FW, HW: lengths of right fore- and hind- wings, $F, T$, t1 and t2: lengths of femur, tibia, and tarsomeres 1 and 2 of right hind leg, ctt1: number of ctenidobothria on $\mathrm{t} 1, \mathrm{Mx} 4$ : length of fourth segment of right maxillary palpus, f1... fn: lengths of flagellomeres $1 . . . n$ of right antenna, IO, D and $\mathrm{d}$ : minimum distance between compound eyes, antero- posterior diameter and transverse diameter, respectively, of right compound eye, on dorsal view of head, PO: $d / D$. The type is deposited in the National Insect Collection (CNIN), Zoology Department, Instituto de Biología, Universidad Nacional Autónoma de México, in Mexico City.

\section{RESULTS \\ Family Lachesillidae Pearman \\ Lachesilla cibriani $\mathbf{n}$. sp. Male}

(Figs 1-4)

http://zoobank.org/D691D35C-37B5-4F25-B5C34DE7940A8B20

Diagnosis. Hypandrium of one small, rectangular, almost glabrous, transverse sclerite, strongly sclerotized along posterior border, flanked by large claspers, each rounded proximally, with a field of setae, narrowing posteriorly, curved inwards, articulated distally to a slender, curved outwards, acuminate process. Phallosome Y-shaped, the stem of $27 \%$ of the total length of the phallosome, arms stout, bow-shaped, blunt ended. Paraprocts with curved, sclerotized mesal prong, with a sclerotized band on inner border, partially limiting the sensory fields. Epiproct posteriorly bilobed, each lobe setose.

Color (in $80 \%$ ethanol). Body chestnut brown. Compound eyes black, ocelli hyaline, without pigmented centripetal crescents. Wings hyaline, with slight orange hue. Legs and antennae pale brown. Abdomen creamy, with pale brown subcuticular rings, more pigmented dorsally.

Morphology. Pterostigma elongate, wider posteriorly. Rs-M fused for a short distance. Rs convex distal to M junction, $\mathrm{M}$ concave before forking. Areola postica wide, rounded apically (Fig. 1) Hindwing Rs-M fused for a medium distance (Fig. 2). Hypandrium, claspers and 
phallosome as illustrated in Fig. 3. Paraprocts (Fig. 4) broad, with setae as illustrated, sensory fields round, with 11 trichobothria on basal rosettes. Epiproct (Fig. 4) wide, transverse, almost straight anteriorly, posteriorly bilobed.

Measurements (in $\mu \mathrm{m}$ ). FW: 2169, HW: 1527, F: 467, T: $889, \mathrm{t} 1: 328, \mathrm{t} 2: 88, \mathrm{ctt} 1: 18, \mathrm{f1}: 296, \mathrm{f2}: 267, \mathrm{f3}: 216$, f4: 172, f5: 99, f6: 90, f7: 78, f8: 84, f9: 83, f10: 79, f11: 75, 10 : 352, D: 192, d: 120, IO/d: 2.93, PO: 0.62 .

Type locality. Holotype male. MEXICO. Chiapas. Lagunas de Montebello, 60 km SE Comitán, 1608'39.34" N: 91'43'06.91"W, 1580 m. 11.VIII.1975. Beating Quercus branches with dead leaves, A. N. García Aldrete.

Etymology. This species is dedicated to Dr. David Cibrián Tovar, of the Universidad Autónoma Chapingo, in recognition of his important contributions to the study of forest insects in Mexico.

Remarks. Lachesilla cibriani García Aldrete \& Silva Neto, is assigned to species group Corona, on account of the paraprocts, epiproct and phallosome apodemes; the hypandrium and claspers, however, do not fit well in the structural plan of species group Corona: the hypandrium is a medium sized, almost glabrous rectangular sclerite, quite different from the hypandrium in the known species of Lachesilla in that group, and the claspers are well separated from the sides of the hypandrium, each clasper is a proximally rounded structure, bearing a setal field, narrowing distally, with the end clearly articulated to a curved, slender process directed outwards; in none of the species of the Corona group are the claspers separated from the hypandrium, and in none is there a distal process articulated to the distal ends of the claspers (see García Aldrete, 2017a, b). The hypandrium and claspers in $L$. cibriani are reminiscent to those in the Forcepeta species group (see García Aldrete, 1974; Mockford, 1993) but they are distinct; in the species of the latter group, the hypandrium is a broad, setose sclerite, flanked by the claspers, of one piece, in which a proximal half and a distal process are recognized, but these are never articulated, and the proximal half is never as wide and rounded as in L. cibriani; also, the phallosome apodemes in species of the Forcepeta group are fused to form a rod that only forks distally and extend into membranous, laminar sheets or other processes, absent in L. cibriani, where the phallosome is distinctly Y-shaped. Furthermore, in L. cibriani the hypandrium is small, almost glabrous, lacking setae posteriorly in the middle, therefore, the species can not be assigned to species group Forcepeta. For stability, it is best to assign $L$. cibriani in species group Corona, because we do not know if it could be the male of one of the many species in the group described from females.

The Simojovelensis species group, also known from Chiapas, some $150 \mathrm{Km} \mathrm{NW}$ from the type locality of $L$. cibriani, includes only L. simojovelensis, known from two females (García Aldrete, 2014). L. simojovelensis might be the female of $L$. cibriani, but the possibility seems to be ruled out, as the female $L$. simojovelensis has gonapophyses and ninth sternum of the type found in species group Sclera. A definitive decision could only be taken when $L$. cibriani and $L$. simojovelensis were found together.

\section{ACKNOWLEDGMENTS}

We thank Dr. Edward L. Mockford (Illinois State
University, Normal, Illinois, USA), and Dr. Ranulfo González Obando (Universidad del Valle, Cali, Colombia) for their comments on a previous version of this paper. We also thank Javier García Figueroa (Instituto de Biología, UNAM) for measuring the specimen studied. ANGA thanks Instituto de Biología, UNAM for continuous research support. AMSN thanks Instituto Nacional de Pesquisas da Amazônia (INPA) and Conselho Nacional de Desenvolvimento Científico e Tecnológico do Brasil (CNPq) for support of the PDJ Cnpq research grant (Process: 400.282/2017-8).

\section{LITERATURE CITED}

García Aldrete, A. N. 1974. A classification above species level of the genus Lachesilla Westwood (Psocoptera: Lachesillidae). Folia Entomológica Mexicana, (27): $1-88$.

García Aldrete, A. N. 1981. The species group Palmicola of the genus Lachesilla (Psocoptera: Lachesillidae). Folia Entomológica Mexicana, (47): 25-35.

García Aldrete, A. N. 1982. The species group riegeli of the genus Lachesilla (Psocoptera: Lachesillidae). Diagnoses, records and descriptions of new species. Zoologischer Anzeiger, Jena, (209): 196-210.

García Aldrete, A. N. 1983. The Lachesilla centralis complex: descriptions and records of constituent species (Insecta: Psocoptera: Lachesillidae). Folia Entomológica Mexicana, (55): 13-29.

García Aldrete, A. N. 1985. The species of Lachesilla in the group Texcocana (Psocoptera: Lachesillidae). Descriptions, records and relationships. Folia Entomológica Mexicana, (65): 37-62.

García Aldrete, A. N. 1986. The species group Patzunensis of the genus Lachesilla (Psocoptera: Lachesillidae). Anales del Instituto de Biología, Universidad Nacional Autónoma de México, Serie Zoología, (56-1): 53-72.

García Aldrete, A. N. 1990. Sistemática de las especies de Lachesilla en el grupo Rufa. Distribución geográfica y afinidades (Insecta: Psocoptera: Lachesillidae). Anales del Instituto de Biología, Universidad Nacional Autónoma de México, Serie Zoología, (61-1): 13-97.

García Aldrete, A. N. 2009. New species and records of Psocoptera (Insecta) from Argentina. Zootaxa, (2219): $1-17$.

García Aldrete, A. N. 2010. New Lachesilla (Psocodea:'Psocoptera': Lachesillidae) from Peru and Mexico, based on males with one clunial apophysis. Revista Mexicana de Biodiversidad, (81): 309-314.

García Aldrete, A. N. 2011a. A new species of Lachesilla (Psocodea: 'Psocoptera': Lachesillidae) from Dominica, representing a new species group. Revista Mexicana de Biodiversidad, (82): 481-484.

García Aldrete, A. N. 2011b. Psocoptera (Insecta) de Chiapas. Pp. 315-343. En: Álvarez, F. (Coordinador general). Chiapas. Estudios sobre su diversidad biológica. Instituto de Biología, Universidad Nacional Autónoma de México. México, D. F.

García Aldrete, A. N. 2014. A new Lachesilla from Chiapas, Mexico, representing a new species group (Psocodea: 'Psocoptera': Lachesillidae). Dugesiana, (21-1): 33-35.

García Aldrete, A. N. 2017a. New species of Lachesilla (Psocodea: Psocomorpha: Lachesillidae), in species 
group Corona, from Guerrero and Chiapas, Mexico. Dugesiana, (24-2): 171-176.

García Aldrete, A. N. 2017b. New species of Lachesilla

(Psocodea: Psocomorpha: Lachesillidae), in species group corona, from southern Mexico and Central America. Zootaxa, (4347-2): 201-227.

García Aldrete, A. N. \& Mockford, E. L. 2011. The Male Lachesilla sulcata García Aldrete 1986 and a Reappraisal of Species Group Patzunensis (Psocodea:'Psocoptera': Lachesillidae). Proceedings of the Entomological Society of Washington, (113-4): 417-425.
Mockford, E. L. 1993. North American Psocoptera (Insecta). Flora \& Fauna Handbook No. 10. Sandhill Crane Press, Inc. Gainesville, Florida. Leiden, The Netherlands.

Mockford, E. L. \& García Aldrete, A. N. 1996. "Psocoptera". Capítulo 16. pp. 175-205. En: Llorente Bousquets, J., García Aldrete, A. N. \& González Soriano, E. (editores). Biodiversidad, taxonomía y biogeografía de artrópodos de México: Hacia una sintesis de su conocimiento. Instituto de Biología, Universidad Nacional Autónoma de México. México, D. F.

Recibido: 17 de abril 2018

Aceptado: 24 de mayo 2018

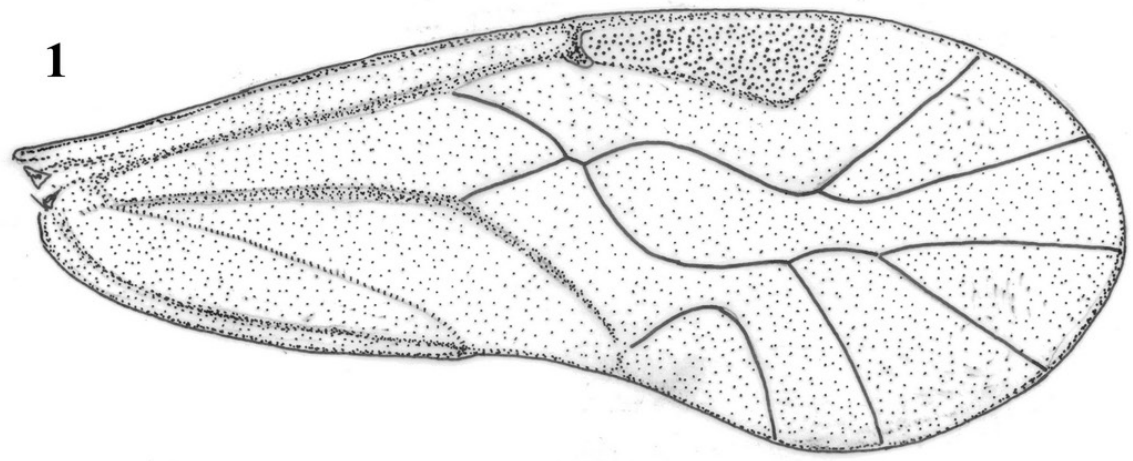

2

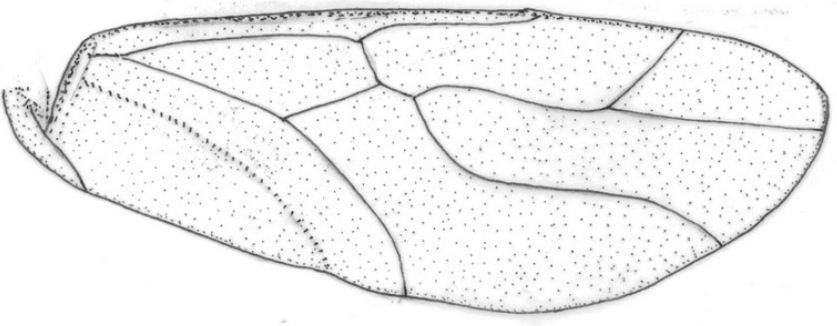

1.0
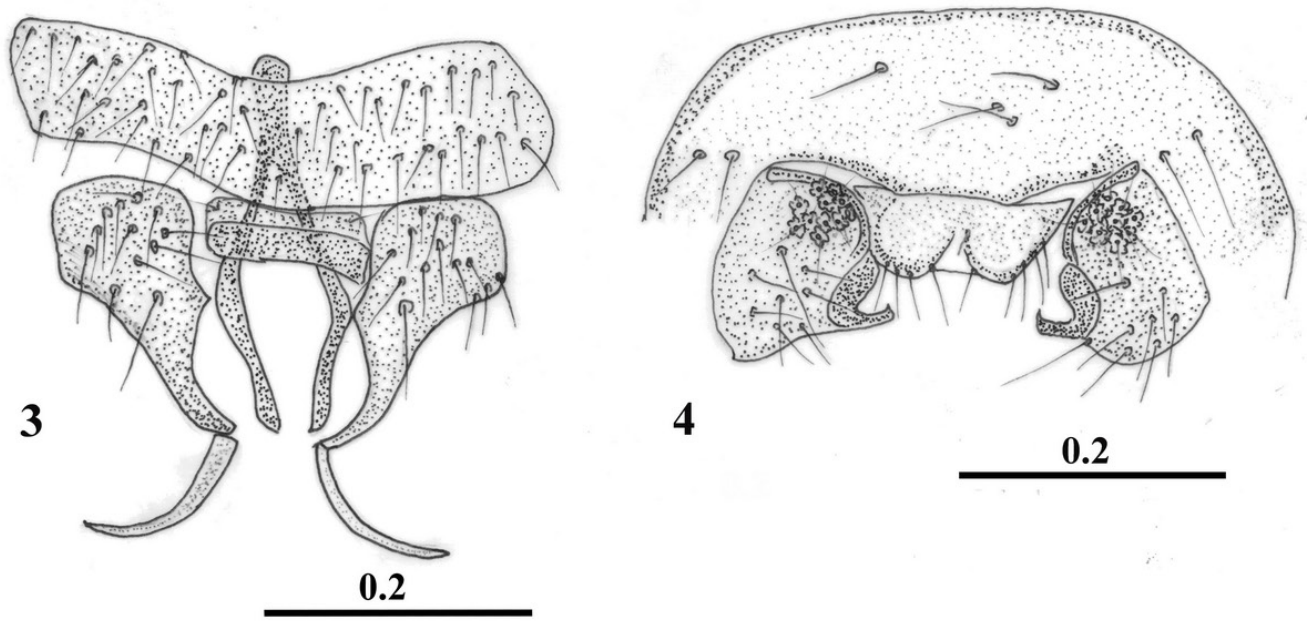

4

\section{2}

Figures 1-4. Lachesilla cibriani García Aldrete \& Silva Neto. Male. 1. Forewing. 2. Hindwing. 3. Phallosome, hypandrium and claspers. 4. Clunium, paraprocts and epiproct. Scales in $\mathrm{mm}$. 